\title{
Endoscopic review of patients who have had gastric surgery
}

\author{
P A FARRANDS, J R S BLAKE, I D ANSELL, R E COT'TON, J D HARDCASTLE
}

\begin{abstract}
Seventy one patients who had had operations on their stomachs over 15 years previously were examined by endoscopy and multiple mucosal biopsy sampling. Sixty six had histologically proved gastritis ( 56 chronic atrophic gastritis, 10 superficial gastritis), 38 intestinal metaplasia, and 11 epithelial dysplasia. In three cases the epithelial dysplasia was severe (carcinoma in situ). One patient had an infiltrating carcinoma and another, whose biopsy appearances were reported as severe dysplasia, developed a carcinoma of the stomach eight months later.

All patients having undergone gastric surgery more than five years previously should be screened endoscopically and any found to have moderate dysplasia subjected to regular endoscopic screening thereafter. Patients with severe dysplasia (carcinoma in situ) should be considered for radical surgery.
\end{abstract}

\section{Introduction}

The overall five year survival rate in Europe for carcinoma of the stomach is $9 \%$ and has remained unchanged for two decades. ${ }^{1}$ Among the possible risk factors predisposing to gastric cancer previous gastric surgery for benign disease appears to be important. $^{2}$

Cancer of the gastric stump after resection for benign ulcer disease develops after a latent period of at least five years, ${ }^{3}$ most patients developing their cancer after 20-30 years. ${ }^{45}$ In retrospective studies of patients with gastric cancer a previous

University Hospital, Nottingham NG7 2UH

P A FARRANDS, BM, FRCS, surgical research fellow, Cancer Research Campaign laboratories and department of surgery

$J$ J S BLAKE, MB, FRCS, lecturer in surgery

J D HARDCASTLE, MCHIR, FRCS, professor of surgery

City Hospital, Nottingham NG5 1PB

I D ANSELL, MA, FRCPATH, consultant pathologist

R E COTTON, MD, FRCPATH, special professor in diagnostic oncology

Correspondence to Mr P A Farrands. history of a gastric operation is present in $2-8 \%$ of cases. ${ }^{6-8}$ The type of operation for benign peptic ulcer disease (gastric resection or gastroenterostomy) does not appear to affect the subsequent late development of cancer. ${ }^{5-9}$ Operations for peptic ulcer disease result in hypochlorhydria or achlorhydria and increased biliary and pancreatic reflux, and it is believed that these factors lead to chronic atrophic gastritis and intestinal metaplasia, which may then progress to carcinoma. ${ }^{910}$ Both of these lesions occur in up to half of patients who have had a gastrectomy ${ }^{11}$ and as a marker for gastric cancer are far too frequent a finding. Morson $e t$ al $^{12} \mathrm{drew}$ attention to the relevance of epithelial dysplasia as a premalignant condition and suggested a prospective study to evaluate its role as an epidemiological marker for gastric cancer.

The present study was undertaken to determine the incidence of gastric cancer in patients having previously undergone gastric surgery and to assess the relevance of epithelial dysplasia as a premalignant condition.

\section{Patients and methods}

Patients who had had gastric operations for benign peptic ulceration before 1964 were identified from the theatre operation registers of the Nottingham City and General Hospitals. The case notes of patients under 75 were then retrieved from the respective hospital's medical records department and help obtained from the Nottingham Family Practitioner Committee in identifying patients' current addresses and general practitioners. Questionnaires were sent to general practitioners asking permission to include their patients in the study and, if obtained, letters then sent to patients inviting them to attend for interview. At interview the study was explained, a clinical history taken and Visick grade assessed, ${ }^{13}$ and a physical examination performed. Investigations at the time of interview were a full blood count, estimation of serum vitamin $B_{12}$ and folate concentrations, and liver function tests. If patients were willing to participate day case endoscopy sessions were arranged, when patients underwent fibreoptic oesophagogastroscopy under diazepam (Valium) sedation with an Olympus T scope. All gastroscopies were performed by PAF, who at the same time took multiple brushings for cytological study and biopsy specimens (five to 10 per patient) for histological examination. Sites of biopsy sampling included the gastroenterostomy or pylorus, or both, the lesser curvature, the fundus, and the cardia. Details of gastroscopic findings and biopsy sites were recorded. Cytological and histological examinations were carried out independently by REC and IDA. 


\section{HISTOLOGICAL METHODS}

All specimens were fixed in formol saline and embedded in paraffin; $5 \mu \mathrm{m}$ thick sections were cut and stained with haematoxylin and eosin and the combined periodic-acid Schiff and alcian blue technique for mucins.

The presence of an inflammatory infiltrate in the lamina propria with or without epithelial changes was termed gastritis and classified as:

Acute gastritis-A pronounced infiltration of neutrophil leucocytes in the mucosa with or without crypt abscess formation.

Superficial gastritis-Gastric mucosa of normal depth with no atrophy of specialised cells but an increased chronic inflammatory cell infiltrate of the lamina propria confined to the luminal third of the mucosa.

Chronic atrophic gastritis-Infiltration of chronic inflammatory cells throughout the lamina propria with reduction in depth of mucosa due to partial atrophy of specialised cells which are partly replaced by undifferentiated cells.

Intestinal metaplasia-The presence of goblet cells containing mucin staining positively with alcian blue, frequently associated with Paneth cell metaplasia.

When significant abnormalities were seen they were called reactive epithelial cell change ${ }^{12}$ if of minor degree, restricted to gland necks, and associated with definite inflammation. More severe cytological abnormalities extending on to surface epithelium were termed dysplasia $^{1214}$ and classified as mild, moderate, or severe using the following criteria ${ }^{11}$ :

Mild dysplasia-Surface epithelial cells are tall and hyperchromatic with elongated, pointed nuclei; nuclear:cytoplasmic ratio is increased but nuclei are fairly uniform and arranged basally.

Moderate dysplasia-Nuclei are rounded and the nuclear:cytoplasmic ratio is further increased, some nuclei reach the luminal border of the cell, and pleomorphism and mild architectural abnormalities of the tubules are present.

Severe dysplasia-Nuclei show greater pleomorphism and there is increased architectural abnormality (carcinoma in situ).

TABLE I-Symptoms graded with previous surgery

\begin{tabular}{lrrrrr}
\hline \multirow{2}{*}{ Operation } & \multicolumn{4}{c}{ Visick's grading } & Total \\
\cline { 2 - 5 } & 1 & 2 & 3 & 4 & \\
\hline Vagotomy and pyloroplasty & 9 & 3 & 1 & 13 \\
Vagotomy and gastroenterostomy & 22 & 1 & 1 & 2 \\
$\begin{array}{l}\text { Polya gastrectomy } \\
\text { Billroth I (including antrectomy }\end{array}$ & 18 & 9 & 4 & 31 \\
and vagotomy) & 49 & 15 & 7 & 71 \\
\hline Total & & & & \\
\hline
\end{tabular}

Comparing presence of symptoms in patients after Polya gastrectomy with those after Billroth I gastrectomy: $\chi^{2}=6.076 ; p<0.02$

TABLE II-Endoscopic findings in 71 patients (percentages in parentheses)

\begin{tabular}{lrcc}
\hline \multirow{2}{*}{ Previous operation } & No & \multicolumn{2}{c}{ Gastroscopic findings } \\
\cline { 3 - 4 } & & Normal & Gastritis \\
\hline Vagotomy and pyloroplasty & 13 & $12(92 \cdot 3)$ & $1(7 \cdot 7)$ \\
Polya gastrectomy & 25 & $6(24 \cdot 0)$ & $19(76 \cdot 0)$ \\
Billroth I & 31 & $6(19 \cdot 4)$ & $25(80 \cdot 7)$ \\
Vagotomy and gastroenterostomy & 2 & 1 & 1 \\
\hline Total & 71 & $25(35 \cdot 2)$ & $46(64 \cdot 8)$ \\
\hline
\end{tabular}

\section{Results}

A total of 189 patients who had previously undergone gastric surgery for benign peptic ulceration and who were still alive and living in the area were traced and invited to attend for interview; $85(45.0 \%)$ accepted and $71(37.6 \%)$ agreed to gastroscopy.

The 71 patients who agreed to gastroscopy were aged $50-75$ years (mean 62.2, median 65.5) and had had their initial operation 15-35 years before. Forty nine were found to be free of symptoms on detailed questioning, 15 were Visick grade 2, and only seven were Visick grade 3 (table I). Only three out of 25 patients having had a Polya gastrectomy had symptoms as compared with 13 out of 31 who had had a Billroth I gastrectomy $\left(\chi^{2}=6.076 ; \mathrm{p}<0.02\right)$.

Ten patients had abnormal haematological results, six with a haemoglobin concentration of less than $9 \mathrm{~g} / \mathrm{dl}$ and four with minor abnormalities in liver function values. In three patients the anaemia was due to iron deficiency, in two a vitamin $B_{12}$ deficiency (one with subacute combined degeneration of the cord), and in one the anaemia was normochromic, normocytic.

Tables II and III give the endoscopic and histological findings in the 71 patients. Two patients had carcinoma of the stomach. The first carcinoma was detected endoscopically in a 75 year old man who had undergone a gastroenterostomy 35 years before for a gastric ulcer Questioning elicited symptoms of indigestion and anaemia. $\mathrm{He}$ subsequently underwent a Polya gastrectomy. Histologically the growth had spread through the whole thickness of the stomach wall and affected local lymph nodes. The second patient with carcinoma was a man of 69 who had had a Polya gastrectomy 20 years before and who underwent gastroscopy on three occasions. The first showed polypoid changes at the stoma and the histological picture was reported as severe dysplasia only. These changes were confirmed four months later. On the third occasion the polypoid changes had in creased and the histological finding was a submucosal carcinoma. Laparotomy confirmed a submucosal carcinoma $(1 \times 2 \mathrm{~cm})$ confined to the mucosa. A secondary tumour $0.5 \times 0.3 \mathrm{~cm}$ was present in the right lobe of the liver.

Forty six patients had endoscopic evidence of gastritis (red hyperaemic mucosa with contact bleeding). Sixty six $(93.0 \%)$ had histological evidence of gastritis, and only five patients had histologically normal stomach mucosa. Fifty six patients had atrophic gastritis and 10 superficial gastritis.

There was no correlation between the presence or absence of symptoms and the histological detection of gastritis, 45 of the 49 patients without symptoms and 21 of the 22 patients with symptoms having histological evidence of gastritis (table IV).

\begin{tabular}{|c|c|c|c|}
\hline & \multicolumn{2}{|c|}{ Histological findings } & \multirow{2}{*}{ Total } \\
\hline & Normal & Gastritis & \\
\hline $\begin{array}{l}\text { Presence of symptoms } \\
\text { Asymptomatic }\end{array}$ & $\begin{array}{l}1 \\
4\end{array}$ & $\begin{array}{l}21 \\
45\end{array}$ & $\begin{array}{l}22 \\
49\end{array}$ \\
\hline Total & 5 & 66 & 71 \\
\hline
\end{tabular}

Thirty eight patients $(53.5 \%)$ had intestinal metaplasia, only two of whom did not have associated chronic gastritis evident in the gastric biopsy specimens; both of these were superficial biopsy specimens in which only superficial gastritis could be seen (table III).

Fifteen patients had regenerative epithelial cell change; $11(15.5 \%)$

TABLE III-Histological findings in 71 patients who had previously undergone gastric operations for benign conditions (percentages in parentheses)

\begin{tabular}{|c|c|c|c|c|c|c|c|c|c|}
\hline \multirow{2}{*}{ Operation } & \multirow{2}{*}{ Normal } & \multirow{2}{*}{$\underset{\text { gastritis }}{\text { Superficial }}$} & \multirow{2}{*}{$\begin{array}{l}\text { Atrophic } \\
\text { gastritis }\end{array}$} & \multirow{2}{*}{$\begin{array}{l}\text { Intestinal } \\
\text { metaplasia }\end{array}$} & \multirow{2}{*}{$\begin{array}{l}\text { Regenerative } \\
\text { epithelial } \\
\text { cell change }\end{array}$} & \multicolumn{3}{|c|}{ Dysplasia } & \multirow{2}{*}{ Cancer } \\
\hline & & & & & & Mild & Moderate & Severe & \\
\hline $\begin{array}{l}\text { Vagotomy and pyloroplasty }(n=13) \\
\text { Polya gastrectomy }(n=25)\end{array}$ & $\begin{array}{l}1(7 \cdot 7) \\
2(8 \cdot 0)\end{array}$ & $\begin{array}{l}3(23 \cdot 1) \\
4(16 \cdot 0)\end{array}$ & $\begin{array}{r}9(69 \cdot 2) \\
19(76 \cdot 0)\end{array}$ & $\begin{array}{r}3(23 \cdot 1) \\
14(56 \cdot 0)\end{array}$ & $\begin{array}{l}1(7 \cdot 7) \\
4(16 \cdot 0)\end{array}$ & \multicolumn{2}{|l|}{$4(16 \cdot 0)$} & \multirow{2}{*}{\multicolumn{2}{|c|}{$\begin{array}{l}1 \text { progressing } \\
\text { over } 8 \text { months } \\
\text { to carcinoma } \\
1 \text { carcinoma } \\
1+\text { stomach } 1\end{array}$}} \\
\hline $\begin{array}{l}\text { Billroth I }(n=31) \\
\text { Vagotomy and gastroenterostomy }(n=2)\end{array}$ & $2(6.5)$ & $3(9 \cdot 7)$ & $26(83 \cdot 9)$ & $19(61 \cdot 3)$ & $10(32 \cdot 3)$ & $2(6 \cdot 5)$ & 2 & & \\
\hline \multirow[t]{2}{*}{ Total } & $5(7 \cdot 0)$ & $10(14 \cdot 1)$ & $56(78 \cdot 9)$ & $38(53.5)$ & $15(21 \cdot 1)$ & 6 & 2 & 3 & \multirow[t]{2}{*}{2} \\
\hline & & & & & & & $11(15 \cdot 5)$ & & \\
\hline
\end{tabular}


had dysplasia-six mild, two moderate, and three severe (carcinoma in situ). In the two cases of cancer of the stomach severe dysplasia was present in the adjacent tissue samples. No correlation between symptoms and the presence of epithelial dysplasia in the stomach was found, eight of the 11 patients with dysplasia being Visick grade 1 (table V). Table $\mathrm{V}$ summarises the findings in the patients with cancer and dysplasia. In only one patient with mild dysplasia were chronic atrophic gastritis and intestinal metaplasia not present. Furthermore, sections from the stomach of the two patients with carcinoma showed severe dysplasia, atrophic gastritis, and intestinal metaplasia in areas adjacent to the cancer.

TABLE $\mathrm{v}-$ Summary of findings in 71 patients with dysplasia and carcinoma of stomach (number $=11$; percentages in parentheses)

\begin{tabular}{|c|c|c|c|c|c|c|}
\hline \multirow{2}{*}{$\begin{array}{l}\text { Gastritis on } \\
\text { endoscopy }\end{array}$} & \multirow{2}{*}{$\begin{array}{c}\text { Symptoms on } \\
\text { interview }\end{array}$} & \multirow{2}{*}{$\begin{array}{l}\text { Chronic } \\
\text { atrophic } \\
\text { gastritis }\end{array}$} & \multirow{2}{*}{$\begin{array}{l}\text { Intestinal } \\
\text { metaplasia }\end{array}$} & \multicolumn{3}{|c|}{ Degree of dysplasia } \\
\hline & & & & Mild & Moderate & Severe \\
\hline $9(81 \cdot 8)$ & $3(27 \cdot 3)$ & $11(100 \cdot 0)$ & $10(90.9)$ & 6 & 2 & $3^{*}$ \\
\hline
\end{tabular}

*1 associated with carcinoma, 1 progressing to carcinoma.

\section{BRUSH CYTOLOGY}

Brush cytology specimens were examined from all cases and assessed entirely independently of histological, clinical, and gastroscopic findings. Six patients had cytological preparations containing severe or mild cellular abnormalities (table VI). When results were compared with the histological biopsy reports four of the patients had associated histological dysplasia (all three cases of severe dysplasia and carcinoma being identified) and two had normal histological biopsy reports. Both patients with histological biopsy reports of moderate dysplasia and five of the six patients with mild dysplasia had normal or inadequate cytological preparations.

TABLE VI-Correlation of cytological abnormalities with histological report

\begin{tabular}{lccc}
\hline \multicolumn{1}{c}{$\begin{array}{c}\text { Abnormalities } \\
\text { on histology }\end{array}$} & $\begin{array}{c}\text { Severe } \\
\text { cytological } \\
\text { atypia }\end{array}$ & $\begin{array}{c}\text { Mild } \\
\text { cytological } \\
\text { atypia }\end{array}$ & $\begin{array}{c}\text { Normal or } \\
\text { inadequate } \\
\text { cytological } \\
\text { preparations }\end{array}$ \\
\hline $\begin{array}{l}\text { Severe dysplasia }(n=3) \\
\text { Moderate dysplasia }(n=2)\end{array}$ & 3 & & 2 \\
$\begin{array}{l}\text { Mild dysplasia }(n=6) \\
\text { No evidence of dysplasia }(n=60)\end{array}$ & 3 & 1 & 5 \\
\hline Total & 3 & 58 \\
\hline
\end{tabular}

Technical imperfections comprised several types: (1) very scanty yield of epithelial cells; (2) masking of epithelial cells by erythrocytes; (3) poor smearing of cells, which stayed in large clumps and did not allow detailed examination; (4) occasionally the presence of large numbers of polymorphs.

Neutrophil leucocytes were frequently seen in smears from the stomal area but showed no obvious relation to the presence or absence of dysplastic epithelial change.

\section{Discussion}

Endoscopic screening of 71 patients who had had a gastrectomy disclosed two $(2 \cdot 8 \%)$ with infiltrating carcinomas. One had had a Polya gastrectomy and the other a gastroenterostomy performed 20 and 35 years before, respectively. Schrumpf $e t$ al ${ }^{15}$ found four cases of infiltrating carcinoma on endoscopy among 108 patients who had had a Billroth I gastrectomy. In a series of 214 patients who had had a Billroth type II gastrectomy Domellof and Janunger ${ }^{8}$ found four with infiltrating carcinomas and one with "precancerous change"; of 74 patients who had had Billroth I operations, four had carcinomas $(5 \cdot 4 \%)$. Savage and Jones ${ }^{11}$ failed to confirm the high incidence of cancer arising in the gastric remnant in England, but it appears that the incidence of gastric cancer after gastric resection ranges from $2 \%$ to $5 \%{ }^{16}$

Gastric mucosal abnormalities occur more frequently in patients after gastric resection than in age and sex matched controls. ${ }^{11}{ }^{12}$ Sixty six of the 71 patients subjected to endoscopy in our study $(93.0 \%)$ had histological evidence of gastritis, 56 $(78.9 \%)$ having chronic atrophic gastritis and $10(14.1 \%)$ superficial gastritis. Suirala $e t a^{17}$ in a prospective survey of 116 patients with atrophic gastritis found 10 cases of carcinoma that had developed during a follow up period of 20 years, whereas none developed in similar groups of patients with normal stomachs or with superficial gastritis. The prevalence of chronic atrophic gastritis, however, increases with age in normal people as shown by Suirala $e t a l,{ }^{18}$ who found atrophic gastritis in $28 \%$ of those between 16 and 65 years and $54 \%$ of those over 50 . As a marker for gastric cancer, chronic atrophic gastritis is clearly far too common a finding.

Thirty eight of our patients had evidence of intestinal metaplasia $(53.5 \%)$. Only two of these did not have chronic atrophic gastritis. Savage and Jones ${ }^{11}$ found intestinal metaplasia in 29 of 63 patients in association with either moderate or severe gastritis, and there is clearly a strong connection between the two conditions. Morson et al ${ }^{12}$ showed that intestinal metaplasia is more common in stomachs with carcinoma than in those removed for benign lesions and detected transition from metaplastic mucosa to frank carcinoma. Reynolds et $a l^{19}$ considered intestinal metaplasia to be premalignant and suggested that all patients with this lesion should have regular endoscopic biopsies and prophylactic surgery in longstanding cases. Suirala et al, ${ }^{18}$ however, found intestinal metaplasia in $24 \%$ of their randomly selected rural population aged over 50 , so that as a sole marker for gastric cancer it must remain insufficient as an indication for radical measures.

Fifteen of our patients had regenerative epithelial cell change, a form of epithelial abnormality associated with acute inflammation or regeneration of the gastric mucosa, or both ${ }^{12}{ }^{14}$; and while it has some of the characteristics common to dysplasia it is not in itself a premalignant condition. ${ }^{12}$

The concept of dysplasia of the gastric mucosa is relatively recent. The lesion has been recognised for more than 10 years ${ }^{14}$ but various terms have been used in different reports ${ }^{11} 12141525-28$ and they do not always denote the same condition when employed in different schemes; Cuello et $a l^{25}$ reviewed this subject recently. The classification of dysplasia employed here is based on that of Morson et al, ${ }^{12}$ since it seemed logical to use a terminology similar to that used in other sites such as cervix and colon.

Eleven patients $(15.5 \%)$ in our study had frank epithelial dysplasia, which was mild in six, moderate in two, and severe in three (two patients with cancer having associated severe dysplasia). A good correlation between chronic atrophic gastritis, intestinal metaplasia (conditions known to be premalignant), and dysplasia was found, only one patient not having evidence of all three conditions in the biopsy specimens. Furthermore, that one of our patients with severe dysplasia progressed to carcinoma suggests that patients with dysplasia are high risk subjects and should be regularly reviewed for gastric abnormalities. It is not enough to rely on symptoms, eight of the 11 patients with dysplasia being asymptomatic. For the most part, mild dysplasia is a reactive change and patients with this condition should be re-examined with the endoscope every five years or so. Review of the two patients with moderate dysplasia at six months showed no change in the histological picture, and at present we recommend a biannual review of patients with moderately severe dysplasia, as suggested by Nagayo. ${ }^{14}$

Severe dysplasia is regarded as carcinoma in situ in most sites of the body, ${ }^{12}$ and our use of the term intramucosal carcinoma is vindicated by the fact that two of the three patients with severe dysplasia had invasive carcinoma either at presentation or subsequently. Savage and Jones ${ }^{11}$ performed a gastrectomy on their one patient with severe dysplasia and found the lesion to be much more extensive than suspected from endoscopic biopsy specimens. In the present study the patient who underwent three biopsies of severe dysplasia and was seen to have frank 
invasive carcinoma on the third endoscopy was found to have a small secondary deposit in the liver at operation, suggesting that we should have operated earlier. With hindsight, in a fit patient we would recommend total gastrectomy for severe dysplasia. Many of the patients at risk are elderly, however, and the indication for total gastrectomy must be interpreted in the light of the clinical condition of the patient.

The interval between the first gastric operation and cancer of the gastric remnant varies from study to study, starting at around 12 years, ${ }^{8}{ }^{916}$ and is probably dependent on the age of the patient at the time of operation and the type of operation performed. Gray and Lofgren ${ }^{29}$ found that six patients with gastric ulcers developed carcinoma on average six years after operation, whereas in 11 patients with duodenal ulcers 15 years elapsed before the carcinoma appeared. Based on this, several authors ${ }^{416}$ have suggested histological and endoscopic screening of patients after 15 years. There have been reports of cancer developing as early as seven years, however, so that a more complete follow up would probably be achieved by beginning screening at five years.

Relying on cytological procedures alone in patients with cancer yields diagnostic accuracy rates ranging from $82 \%$ or less up to $98 \%$ in different series. ${ }^{20-22}$ Gastric washings have been extensively studied with diagnostic accuracy rates of up to $97 \%{ }^{23}{ }^{24}$ All three patients with severe dysplasia (including the two with carcinoma of the stomach) were found to have pronounced cytological atypia. Unfortunately both patients with moderate dysplasia and five of the six with mild dysplasia had no evidence of cytological atypia in the specimens received; hence it must be concluded that accurate diagnosis of epithelial dysplasia requires histological confirmation at present.

All the secretarial work for this study was performed by Mrs C Mangham, without whose help this study could not have been undertaken. We thank Mr T W Balfour for his time and encouragement during the endoscopy sessions, and Mrs J Martin and Mrs M Parker for their invaluable help during nursing and endoscopy sessions.

\section{References}

1 Anonymous. Screening for gastric cancer in the West. Lancet 1978;i: 1023-4.

${ }^{2}$ Rakovec S, Kovie M. Predisposition of the resected stomach for malignancy. World f Surg 1981;5:725-7.

${ }^{3}$ Morgenstern L, Yamakawa T, Seltizer D. Carcinoma of the gastric stump. Am f Surg 1973;125:29-32.

${ }^{4}$ Stalsberg H, Taksdal S. Stomach cancer following gastric surgery for benign conditions. Lancet 1971 ;ii:1175-7.
${ }^{5}$ Eberlein TJ, Lorenzo FV, Marshall MW. Gastric carcinoma following operation for peptic ulcer disease. Ann Surg 1978;187:251-6.

${ }^{6}$ Helsingen N, Hillestad L. Cancer development in the gastric stump after partial gastrectomy for ulcer. Ann Surg 1956;143:173-9.

${ }^{7}$ Liavag K. Cancer development in gastric stump after partial gastrectomy for peptic ulcer. Ann Surg 1962;155:103-5.

${ }^{8}$ Domellof L, Janunger KG. The risk of gastric carcinoma after partial gastrectomy. Am f Surg 1977;134:581-4.

9 Papachristou DN, Agnanti N, Fortner JG. Gastric carcinoma after treatment of ulcer. Am F Surg 1980;139:193-6.

${ }^{10}$ Lambert R. Chronic gastritis. Digestion 1972; 7:83-126.

11 Savage A, Jones S. Histological appearances of the gastric mucosa 15-27 years after partial gastrectomy. $\mathcal{F}$ Clin Pathol 1979;32:179-86.

12 Morson BC, Sobin LH, Grundmann E, Johansen A, Nagayo T, SerckHanssen A. Precancerous conditions and epithelial dysplasia in the stomach. $\mathcal{f}$ Clin Pathol 1980;33:711-21.

${ }^{13}$ Visick AH. A study of the failures after gastrectomy. Ann R Coll Surg Engl $1948 ; 3: 266-84$.

14 Nagayo T. Histological diagnosis of biopsied gastric mucosae with special reference to that of borderline lesions. Gann Monograph on Cancer Research $1971 ; 11: 245-9$.

${ }^{15}$ Schrumpf E, Stadaas J, Myren J, Serck-Hanssen A, Aune S, Osnes M Mucosal changes in the gastric stump 20-25 years after partial gastrectomy. Lancet 1977 ;ii :467-9.

${ }^{16}$ Huibregste K. Endoscopic screening for malignancy in the gastric remnant. In: Cotton PB, ed. Proceedings of 2nd BSG international workshop on early gastric cancer. Smith Kline and French Laboratories, 1981.

17 Suirala M, Lehtola J, Ihamaki T. Atrophic gastritis and its sequelae. Scand $\mathcal{F}$ Gastroenterol 1974;9:441-6.

18 Suirala M, Isokosk $M$, Vars K, Kekk M. Prevalence of gastritis in a rura population. Scand f Gastroenterol 1968;3:211-23

19 Reynolds KW, Johnson AG, Fox B. Is intestinal metaplasia of the gastric mucosa a premalignant lesion? Clin Oncol 1975;1:101-9.

20 Smithies A, Lovell D, Hishorn S, et al. Value of brush cytology in diagnosis of gastric cancer. Gut 1975;16:395.

21 Young JA, Hughes HE, Lee FD. Evaluation of endoscopic brush and biopsy touch smear cytology and biopsy histology in the diagnosis of carcinoma of lower oesophagus and cardia. F Clin Pathol 1980;33:811.

${ }^{22}$ Keighley MRB, Thompson H, Moore J, Hoare AM, Allan RN, Dykes PW. Comparison of brush cytology before or after biopsy for diagnosis of gastric carcinoma. Br f Surg 1979;66:246-50.

${ }^{23}$ Schade ROK. Gastric cytology. London: Edward Arnold, 1960.

${ }^{24}$ Hussain OAN. Cytological screening for cancer of the stomach. Proceedings of the Royal Society of Medicine 1976;69:489-92.

${ }^{25}$ Cuello C, Correa P, Zarama G, Lopez J, Murray J, Gordillo G. Histopathology of gastric dysplasia. Correlation with gastric juice chemistry. Am F Surg Pathol 1979;3:491-500.

${ }^{26}$ Grundman E. Histological types and possible initial stages in early gastric carcinoma. Beiträge zur Pathologische 1975;154:256-80.

${ }^{27}$ Oehlert W, Keller P, Henke M, Strauch M. Gastric mucosal dysplasias what is their clinical significance ? Front Gastrointest Res 1979;4:173-82

${ }^{28}$ Schade ROK. The borderline between benign and malignant lesions in the stomach. In: Grundmann E, Gruntze H, Witte S, eds. Early gastric cancer. Berlin: Springer-Verlag, 1974:45-53.

${ }^{29}$ Gray HK, Lofgren KA. The significance of ulcerating lesions in the stomach following gastroenterostomy. Surg Gynecol Obstet 1949;89 : 285-91.

(Accepted 24 December 1982)

\section{SAGE flowers in or about July.}

Jupiter claims this, and bids me tell you, it is good for the liver, and to breed blood. A decoction of the leaves and branches of Sage made and drank, saith Dioscorides, provokes urine, brings down women's courses, helps to expel the dead child, and causes the hair to become black. It stays the bleeding of wounds, and cleanses foul ulcers. Three spoonfuls of the juice of Sage taken fasting, with a little honey, doth presently stay the spitting or casting of blood of them that are in a consumption. These pills are much commended; Take of spikenard, ginger, of each two drams; of the seed of Sage toasted at the fire, eight drams; of long pepper, twelve drams; all these being brought into powder, put thereto so much juice of Sage as may make them into a mass of pills, taking a dram of them every morning fasting, and so likewise at night, drinking a little pure water after them. Matthiolus saith, it is very profitable for all manner of pains in the head coming of cold and rheumatic humours: as also for all pains of the joints, whether inwardly or outwardly, and therefore helps the falling-sickness, the lethargy such as are dull and heavy of spirit, the palsy; and is of much use in all defluctions of rheum from the head, and for the diseases of the chest or breast. The leaves of Sage and nettles bruised together, and laid upon the imposthume that rises behind the ears, doth assuage it much. The juice of Sage taken in warm water, helps a hoarseness and a cough. The leaves sodden in wine, and laid upon the place affected with the palsy, helps much, if the decoction be drank: Also Sage taken with wormwood is good for the bloody-flux. Pliny saith, it procures women's courses, and stays them coming down too fast: helps the stinging and biting of serpents, and kills the worms that breed in the ear, and in sores. Sage is of excellent use to help the memory, warming and quickening the senses; and the conserve made of the flowers is used to the same purpose, and also for all the former recited diseases. The juice of Sage drank with vinegar, hath been of good use in time of the plague at all times. Gargles likewise are made with Sage, rosemary, honey-suckles, and plantain, boiled in wine or water, with some honey or allum put thereto, to wash sore mouths and throats, cankers, or the secret parts of man or woman, as need requires. And with other hot and comfortable herbs, Sage is boiled to bathe the body and the legs in the Summer time, especially to warm cold joints, or sinews, troubled with the palsy and cramp, and to comfort and strengthen the parts. It is much commended against the stitch, or pains in the side coming of wind, if the place be fomented warm with the decoction thereof in wine, and the herb also after boiling be laid warm thereunto. (Nicholas Culpeper (1616-54) The Complete Herbal, 1850.) 